\title{
Hygroscopic trend of lyophilized 'mangaba' pulp powder
}

\author{
Juliana Conegero ${ }^{1}$, Luciana C. Ribeiro², Antonio R. G. Monteiro ${ }^{1} \&$ José M. C. da Costa $^{2}$ \\ ${ }^{1}$ Universidade Estadual de Maringá/Centro de Ciências Agrárias/Programa de Pós-Graduação em Ciência de Alimentos. Maringá, PR. E-mail: \\ juconegero@gmail.com (Corresponding author); argmonteiro@uem.br \\ ${ }^{2}$ Universidade Federal do Ceará/Centro de Ciências Agrárias/Departamento de Tecnologia de Alimentos. Fortaleza, CE. E-mail: ribeiro.lucianac@gmail.com; \\ correiacostaufc@gmail.com
}

\section{Key words: \\ Hancornia speciosa Gomes \\ sorption isotherm \\ hygroscopicity \\ dehydration}

\begin{abstract}
A B S T R A C T
Mangaba is a widely-consumed fruit in the Northeast of Brazil, which is usually exploited through extractivism. This fruit is rich in various nutrients, especially in vitamin $\mathrm{C}$, with pleasant taste and aroma. The lyophilization process transforms these fruits into amorphous powders, which must be analyzed regarding their properties and hygroscopic trend. Thus, the objective of this study was to characterize and evaluate the physico-chemical properties of adsorption isotherms of the lyophilized 'mangaba' pulp powder, with addition of maltodextrin (DE 20). The $\mathrm{pH}$, titratable acidity, soluble solids, ascorbic acid and water activity were analyzed. Regarding the isotherms, the mathematical models of GAB, BET, Oswin, and Henderson were used at temperatures of $25,30,35$ and $40{ }^{\circ} \mathrm{C}$. The obtained powder presented $\mathrm{pH}$ of 3.14 , titratable acidity of $1.95 \mathrm{mg}$ of citric acid $100 \mathrm{~g}^{-1}$ of powder,

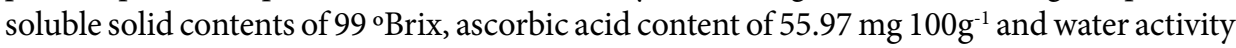
of 0.16 . Henderson was the mathematical model that best fitted the data of the adsorption isotherms at the four evaluated temperatures, with average errors ranging from 5.76 to $9.70 \%$ and $\mathrm{R}^{2}$ from 0.9974 to 0.9995 .
\end{abstract}

Palavras-chave:

Hancornia speciosa Gomes isoterma de sorção

higroscopicidade desidratação

\section{Comportamento higroscópico do pó da polpa de mangaba liofilizada}

\begin{abstract}
R E S U M O
A mangaba é um fruto bastante consumido no Nordeste do Brasil e ainda explorado de maneira extrativista. Os frutos são ricos em vários nutrientes, notadamente em vitamina C, além de possuírem sabor e aroma agradáveis. A liofilização permite a obtenção de pós de natureza amorfa que necessitam de análise de suas propriedades e comportamento higroscópico. O objetivo do presente trabalho foi realizar a caracterização físico-química e avaliação das isotermas de adsorção do pó da polpa de mangaba liofilizada adicionada de maltodextrina (DE 20). Foram realizadas as análises de pH, acidez titulável, sólidos solúveis, ácido ascórbico e atividade de água. Em relação às isotermas, foram empregados os modelos matemáticos de GAB, BET, Oswin e Henderson, nas temperaturas de 25,30 , 35 e $40{ }^{\circ} \mathrm{C}$. O pó obtido apresentou $\mathrm{pH}$ de 3,14, acidez titulável de $1,95 \mathrm{mg} 100 \mathrm{~g}^{-1}$ de ácido cítrico, teor de sólidos solúveis de $99^{\circ}$ Brix, teor ácido ascórbico de 55,97 mg $100 \mathrm{~g}^{-1}$ e atividade de água de 0,16 . O melhor ajuste de modelo matemático foi o de Henderson nas quatro temperaturas avaliadas, em que apresentou erros médios de 5,76 a 9,70\% e $\mathrm{R}^{2}$ de 0,9974 a 0,9995.
\end{abstract}




\section{INTRODUCTION}

'Mangaba' (Hancornia speciosa Gomes) is a Brazilian native tree, whose fruits have important properties, such as high contents of vitamin $\mathrm{C}$ and antioxidants. Thus, they are consumed as fresh fruits and also used as raw material for the production of various products (Soares et al., 2011).

'Mangaba' fruits are highly perishable and, according to Campos et al. (2011), preservation methods are needed to increase their shelf life and maintain their quality. The fruit pulp industry uses drying methods, which concentrate the raw material components and allow the product to be stored for longer periods, even at room temperature (Silva et al., 2014).

According to Oikonomopoulou et al. (2011), the lyophilization method removes the water from fruits through sublimation, applying vacuum and low temperature, which result in products with high rehydration capacity. This drying method allows to maintain the organoleptic characteristics of the fruits after dehydration.

The evaluation of sorption isotherms to define the hygroscopic equilibrium of products is important to understand the hygroscopic trend under different conditions of temperature and air humidity, predict chemical, enzymatic and microbiological reactions, and develop appropriate packaging for storage (Oliveira et al., 2011).

Several mathematical models are used to determine the sorption isotherms; however, according to Moreira et al. (2013), the accuracies of these models depend on specific ranges of water activity or types of food. Therefore, the use of only one equation model for isotherm analysis of various types of foods is not possible due to specific conditions of water activity and food composition.

Thus, the main objectives of this study were to obtain the 'mangaba' pulp powder, characterize its physicochemical properties and evaluate the hygroscopic trend of the lyophilized mangaba pulp powder through adsorption isotherms, aiming to find the best storage conditions for this product.

\section{Material ANd Methods}

Frozen pulps of 'mangaba' were acquired from a pulp industry in Natal, Rio Grande do Norte, Brazil, taken to the Laboratory of Food Drying and Quality Control of the Federal University of Ceará, and stored at $-18^{\circ} \mathrm{C}$.

These pulps were combined with maltodextrin at $30 \%$ (dextrose equivalent of 20), placed on stainless steel trays and stored in an ultra-freezer (CL90-40V, Terroni) for freezing during $24 \mathrm{~h}$. They were then dehydrated, during $24 \mathrm{~h}$ in a lyophilizer (L101, Liotop). The obtained product was stored in laminated polyethylene packages.

The lyophilized 'mangaba' pulp powder was physicochemically characterized. The $\mathrm{pH}$, titratable acidity and soluble solids were analyzed according to the method described by the Adolfo Lutz Institute (IAL, 2008). The ascorbic acid was determined according to the method described by Strohecker
\& Henninger (1967), and the water activity was measured in a water activity meter (4TEV, Aqualab). All analyses were performed with three replications.

The moisture adsorption isotherm was determined through the statistic gravimetric method described by Greenspan (1977), using saturated salt solutions such as $\mathrm{CH}_{3} \mathrm{COOK}, \mathrm{K}_{2} \mathrm{CO}_{3}, \mathrm{NaBr}$, $\mathrm{SnCl}_{2}, \mathrm{KCl}$, and $\mathrm{BaCl}_{2}$ (Table 1) in glass cells, at $21 \pm 2{ }^{\circ} \mathrm{C}$.

Aluminum crucibles with approximately $0.2 \mathrm{~g}$ of each sample, weighed with three replications, were placed into cells containing the saturated solutions, where they remained for 3 days to reach equilibrium, i.e., until no weight change could be detected by weighing on the analytical balance (B-TEC-210A, Tecnal).

Weight measurements were performed every $24 \mathrm{~h}$ until reaching the equilibrium condition. Subsequently, the water activity was measured in the Aqualab $4 \mathrm{TEV}$, at four different temperatures $\left(25,30,35\right.$ and $\left.40^{\circ} \mathrm{C}\right)$. The crucibles containing the samples were then placed into a vacuum oven at $70{ }^{\circ} \mathrm{C}$ to evaluate the final moisture content of the samples.

The moisture equilibrium $\left(\mathrm{X}_{0}\right)$ was calculated by the difference between the sample weights at equilibrium and dry conditions, using the Eq. 1.

$$
\mathrm{X}_{0}=\frac{\mathrm{M}_{\mathrm{eq}}-\mathrm{M}_{\mathrm{s}}}{\mathrm{M}_{\mathrm{s}}}
$$

where:

$\mathrm{X}_{0} \quad$ - moisture equilibrium ( $\mathrm{g}$ of water per $\mathrm{g}$ of dry solids);

$\mathrm{M}_{\text {eq }}$ - sample weight at equilibrium (g); and,

$\mathrm{M}_{\mathrm{s}}$ - sample dry weight (g).

The experimental data of the adsorption isotherms were adjusted to the mathematical models GAB, BET, Henderson, and Oswin, as described in Eqs. 2 to 5:

- GAB

$$
\mathrm{X}_{0}=\frac{\mathrm{X}_{\mathrm{m}} \mathrm{CKa}_{\mathrm{w}}}{\left(1-\mathrm{Ka}_{\mathrm{w}}\right)\left(1 \mathrm{Ka}_{\mathrm{w}}+\mathrm{CKa} \mathrm{w}_{\mathrm{w}}\right)}
$$

- BET

$$
\mathrm{X}_{0}=\frac{\mathrm{X}_{\mathrm{m}} \mathrm{Ca}_{\mathrm{w}}}{1-\mathrm{a}_{\mathrm{w}}}\left[\frac{1-(\mathrm{n}+1)\left(\mathrm{a}_{\mathrm{w}}\right)^{2}+\mathrm{n}\left(\mathrm{a}_{\mathrm{w}}\right)^{\mathrm{n}+1}}{1-(1-\mathrm{C}) \mathrm{a}_{\mathrm{w}}-\mathrm{C}\left(\mathrm{a}_{\mathrm{w}}\right)^{\mathrm{n}+1}}\right]
$$

- Henderson

$$
\mathrm{X}_{0}=\left[\frac{-\ln \left(1-\mathrm{a}_{\mathrm{w}}\right)}{\mathrm{b}}\right]^{\frac{1}{\mathrm{a}}}
$$

Table 1 . Water activity $\left(\mathrm{a}_{\mathrm{w}}\right)$ of saturated salt solutions at $21 \pm 2{ }^{\circ} \mathrm{C}$

\begin{tabular}{cc}
\hline Salt solutions & $\mathbf{a}_{\mathbf{w}}$ \\
$\mathrm{CH}_{3} \mathrm{COOK}$ & 0.21 \\
$\mathrm{~K}_{2} \mathrm{CO}_{3}$ & 0.44 \\
$\mathrm{NaBr}$ & 0.58 \\
$\mathrm{SnCl}_{2}$ & 0.76 \\
$\mathrm{KCl}$ & 0.84 \\
$\mathrm{BaCl}_{2}$ & 0.90 \\
\hline
\end{tabular}


- Oswin

$$
X_{0}=a\left(\frac{a_{w}}{1-a_{w}}\right)^{b}
$$

where:

$a_{w} \quad$ - water activity;

$\mathrm{X}_{\mathrm{m}}$ - moisture content in the molecular monolayer ( $\mathrm{g}$ of water per g of dry solids);

$\mathrm{X}_{0} \quad$ - moisture equilibrium ( $\mathrm{g}$ of water per g of dry solids);

C - BET constant, related to the sorption heat of the molecular layer; and,

$\mathrm{a}, \mathrm{b}$, and $\mathrm{K}$ - are parameters of adjustment.

The statistical program Statistica 7.0 was used to fit the data to the models. The error values (E) were calculated according to the Eq. 6 (Kurozawa et al., 2005):

$$
E=\frac{100}{n} \sum_{i=1}^{n} \frac{\left|\left(M_{i}-M_{p i}\right)\right|}{M_{i}}
$$

where:

$$
\begin{array}{ll}
E & \text { - mean relative error; } \\
M_{i} & \text { - value experimentally obtained; } \\
M_{p i} & \text { - value obtained by the model; and, } \\
n & \text { - number of experimental data. }
\end{array}
$$

\section{Results AND Discussion}

The characterization of the lyophilized 'mangaba' pulp powder with $30 \%$ of maltodextrin is shown in Table 2 . The lyophilized 'mangaba' pulp powder has acid characteristic, which contributes to the stability of the product. Santos et al. (2012) physico-chemically characterized lyophilized 'mangaba' pulp and found $\mathrm{pH}$ values near 3.01, even though no drying adjuvant was added. These figures are important to maintain the quality of the product, since according to Breda et al. (2012), $\mathrm{pH}$ values from 5 to 7 cause enzymatic browning in fruits.

The titratable acidity found in the present study $(1.95 \mathrm{mg}$ $\left.100 \mathrm{~g}^{-1}\right)$ is consistent with acidic characteristics that allow the storage of the product. This parameter represents the content of organic acids in the fruit (Soares et al., 2014). Lima et al. (2015) found titratable acidity values in 'mangaba' fruits of

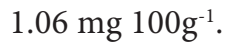

The lyophilized 'mangaba' pulp powder presented soluble solid contents greater than those of other dehydrated products. Santos et al. (2014) found soluble solid contents of $93^{\circ}$ Brix in atomized guava powder, while Oliveira et al. (2014b) found $92.67{ }^{\circ}$ Brix in lyophilized mombin (Spondias mombin L.)

Table 2. Characterization of the lyophilized mangaba pulp powder with $30 \%$ of maltodextrin

\begin{tabular}{lr}
\hline \multicolumn{1}{c}{ Parameters } & \multicolumn{1}{c}{ Values } \\
$\mathrm{pH}$ & $3.14 \pm 0.01$ \\
Titratable acidity (\%citric acid) & $1.95 \pm 0.06$ \\
Soluble solids ( ${ }^{\circ}$ Brix) & $99.00 \pm 0.58$ \\
Ascorbic acid (mg $100 \mathrm{~g}^{-1}$ ) & $55.97 \pm 2.84$ \\
Water activity & $0.16 \pm 0.00$ \\
\hline
\end{tabular}

pulp powder. Sousa et al. (2015) compared the soluble solid contents of 'atemoya' (Annona cherimola Mill $\times$ A. squamosa L.) powder with the ones in the fruit pulp and found greater soluble solid contents in the powder due to the addition of a drying adjuvant. Soluble solids in fruits are related to compounds that influence the acceptance by the consumers, such as the taste of the product (Santos et al., 2012).

The ascorbic acid content was lower than that found by Soares et al. (2014) (188.72 mg 100g-1) in lyophilized 'mangaba' without addition of adjuvants. Oliveira et al. (2014b) found $90.46 \mathrm{mg}$ of ascorbic acid per $100 \mathrm{~g}$ of lyophilized mombin pulp powder with $17 \%$ of maltodextrin, and attributed these low values to the addition of a drying adjuvant. Despite the addition of drying adjuvant, the values of ascorbic acid found in $100 \mathrm{~g}$ of the lyophilized 'mangaba' pulp powder were greater than the daily intake value recommended by the Brazilian Health Regulatory Agency (Brasil, 2005), which is $45 \mathrm{mg}$. Moreira et al. (2013) found $54.47 \mathrm{mg}$ of ascorbic acid per 100 $\mathrm{g}$ of lyophilized mango pulp.

The values of water activity in the lyophilized 'mangaba' pulp powder were low. According to Soares et al. (2014), the water activity values of the 'mangaba' fresh pulp are within 0.97 and 0.98 . The dehydration process of the pulp and the addition of maltodextrin in the pulp powder reduce the water activity and increase the soluble solids (Sousa et al., 2015). Dieb et al. (2015) found water activity values between 0.25 and 0.32 and reported low water activity values in dehydrated soursop (Annona muricata L.).

The moisture equilibrium $\left(\mathrm{X}_{0}\right)$ of the evaluated isotherms increased with the increasing water activity (Figure 1). The same trend was found by Moreira et al. (2013) in an experiment with lyophilized mango.

This trend is a characteristic of amorphous powders, such as the 'mangaba' pulp, after subjected to lyophilization with the addition of maltodextrin (Muzaffar \& Kumar, 2016). The moisture equilibrium also increased with the increasing temperatures. This increase was also observed by Ribeiro et al. (2016) in lyophilized west indian cherry (Malpighia glabra Millsp.) pulp powder, which is rich in sugars and has high tendency to absorb water at higher temperatures. According to

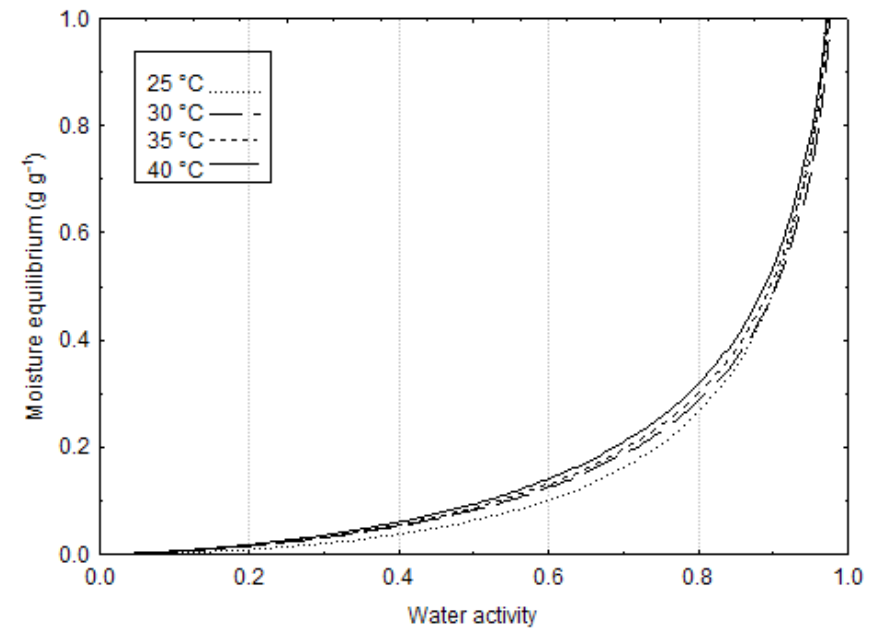

Figure 1. Moisture equilibrium of lyophilized 'mangaba' pulp powder depending on the water activity 
Oliveira et al. (2011), besides the content of sugars, the porosity and soluble compounds of lyophilized foods also contribute to increasing their water content.

Powders are susceptible to different physical changes according to the relative humidity of their environment. The lyophilized 'mangaba' pulp powder showed a high moisture gain from a relative humidity of $80 \%$ (Figure 1). Therefore, its stability is maintained up to this value, which is the limit value to store this product without degradation caused by physical reactions.

The obtained isotherm had a type III curve, with a "J" shape (Hébrard et al., 2003) and an exponential trend. This type of curve is common in foods that have significant levels of soluble compounds, such as sugars (Lavoyer et al., 2013), although most of the foods show type II curve (sigmoid). A type III curve was also found by Oliveira et al. (2014a) in atomized 'macauba' (Acrocomia aculeata (Jacq.) Lodd. Ex Mart.) pulp powder, and by Santana et al. (2015) in lyophilized 'jambolan' (Syzygium cumini Lamarck) pulp.

The results obtained with the applied mathematical models are shown in Table 3 . The GAB model at $40{ }^{\circ} \mathrm{C}$ and Henderson at all evaluated temperatures showed relative errors (E) lower than $10 \%$, which are suitable values for the isotherm analysis (Lomauro et al., 1985). The other relative errors were between 10.43 and $20.55 \%$, which are considered high; thus, the use of these models is inadequate to predict the isotherms, regardless of their coefficients of determination $\left(\mathrm{R}^{2}\right)$.

The moisture content in the monolayer $\left(\mathrm{X}_{\mathrm{m}}\right)$ of the GAB and BET models had no well-defined trend with the increasing temperatures. This result may be due to the high relative errors (E), which hindered the use of these parameters to assess the hygroscopic trend of the lyophilized 'mangaba' pulp powder.

The moisture content in the monolayer $\left(\mathrm{X}_{\mathrm{m}}\right)$ is the moisture content that ensures minimal loss of product quality for a longer period at a certain temperature, with minimal deteriorating reaction rate below this value, except for the oxidation of unsaturated fats (Goula et al., 2008).

Table 3. Adsorption isotherms of lyophilized 'mangaba' pulp powder fitted to mathematical models

\begin{tabular}{|c|c|c|c|c|c|}
\hline \multirow{2}{*}{ Models } & \multirow{2}{*}{ Parameters } & \multicolumn{4}{|c|}{ Temperature $\left({ }^{\circ} \mathrm{C}\right)$} \\
\hline & & 25 & 30 & 35 & 40 \\
\hline \multirow{5}{*}{ GAB } & $\mathrm{Xm}$ & 0.3616 & 0.1225 & 0.1287 & 0.2811 \\
\hline & C & 0.1605 & 0.7215 & 0.7182 & 0.3485 \\
\hline & K & 0.8372 & 0.8998 & 0.9000 & 0.8170 \\
\hline & $\mathrm{R}^{2}$ & 0.9977 & 0.9991 & 0.9992 & 0.9989 \\
\hline & E (\%) & 11.4400 & 12.0700 & 10.4300 & 8.0400 \\
\hline \multirow{5}{*}{ BET } & $\mathrm{Xm}$ & 0.1204 & 0.1043 & 0.0925 & 0.1469 \\
\hline & C & 0.6791 & 1.1978 & 1.4533 & 0.8229 \\
\hline & K & 1.4861 & 1.5517 & 1.4533 & 1.5727 \\
\hline & $\mathrm{R}^{2}$ & 0.9956 & 0.9939 & 0.9943 & 0.9977 \\
\hline & $E(\%)$ & 16.8800 & 20.5300 & 20.5500 & 14.2400 \\
\hline \multirow{4}{*}{ HENDERSON } & a & 0.5887 & 0.6742 & 0.6739 & 0.6885 \\
\hline & b & 3.5137 & 3.7418 & 3.6162 & 3.5405 \\
\hline & $\mathrm{R}^{2}$ & 0.9974 & 0.9993 & 0.9995 & 0.9994 \\
\hline & $E(\%)$ & 9.7000 & 9.7000 & 7.8500 & 5.7600 \\
\hline \multirow{4}{*}{ OSWIN } & a & 0.0756 & 0.0898 & 0.9964 & 0.0996 \\
\hline & b & 0.8604 & 0.7829 & 0.7986 & 0.7962 \\
\hline & $\mathrm{R}^{2}$ & 0.9963 & 0.9960 & 0.9964 & 0.9981 \\
\hline & $E(\%)$ & 17.8600 & 17.9300 & 20.1600 & 15.7900 \\
\hline
\end{tabular}

The parameter $\mathrm{K}$ of the GAB model showed a trend of stabilization, with values below 1 . These values indicate an appropriate physical aspect of the material, without infinite sorption (Chirife et al., 1992).

Oliveira et al. (2014b) found lower $\mathrm{K}$ values with the addition of maltodextrin to lyophilized mombin pulp, which reduced the interaction strength between the water vapor and the solid matrix, compared with the material with no maltodextrin. This result may explain the lower values of this parameter found in the present work. The parameters required for the Henderson $(\mathrm{a}>0$ and $\mathrm{b}<1)$ and Oswin $(\mathrm{a}>0$ and $\mathrm{b}$ between 0 and 1) models (Blahovec, 2004) were met; however, the Oswin model showed high relative errors and, thus, this model is not recommended.

Henderson was the best model to describe the hygroscopic trend of the lyophilized 'mangaba' pulp powder, with the parameters "a" and "b" within the standard values, relative errors lower than $10 \%$, and coefficients of determination $\left(\mathrm{R}^{2}\right)$ near 1. According to Oliveira et al. (2014a), the Henderson model was one of the best models to predict the isotherm of atomized 'macauba' powder with $8 \%$ maltodextrin and water activity between 0.3 and 0.7 . The Henderson model was also reported as the best model to predict isotherms in other works, such as those carried out by Mil et al. (2014) on atomized mango pulp powder and by Santos et al. (2014) on atomized guava pulp powder.

\section{Conchusions}

1. The lyophilized 'mangaba' pulp powder presented low water activity and high content of soluble solids.

2. The lyophilized 'mangaba' pulp powder presented low $\mathrm{pH}$ and titratable acidity, showing the stability and acidic characteristic of the product. Considering its ascorbic acid content, the lyophilized 'mangaba' pulp powder is a source of vitamin C.

3. Henderson mathematical model best fitted to the data of the adsorption isotherms at the four temperatures evaluated, with low relative errors and high coefficient of determination.

\section{Literature Cited}

Blahovec, J. Sorption isotherms in materials of biological origin mathematical and physical approach. Journal of Food Engineering, v.65, p.489-495, 2004. http://dx.doi.org/10.1016/j. jfoodeng.2004.02.012

Brasil. Agência Nacional de Vigilância Sanitária. Resolução RDC n.269, de 22 de setembro de 2005, que dispõe sobre o Regulamento Técnico sobre a ingestão diária recomendada (IDR) de proteína, vitaminas e minerais, Diário Oficial da República Federativa do Brasil, Brasília, DF, 2005.

Breda, C. A.; Sanjinez-Argandoña, E. J.; Correia, C. de A. Shelf life of powdered Campomanesia adamantium pulp in controlled environments. Food Chemistry, v.135, p.2960-2964, 2012. http:// dx.doi.org/10.1016/j.foodchem.2012.07.029

Campos, R. P.; Knoch, B.; Hiane, P. A.; Ramos, M. I. L.; Ramos Filho, M. M. 1-MCP em mangaba armazenadas em temperatura ambiente e a $11{ }^{\circ} \mathrm{C}$. Revista Brasileira de Fruticultura, v.especial, p.206-212, 2011. http://dx.doi.org/10.1590/S0100-29452011000500024 
Chirife, J.; Timmermann, E. O.; Iglesias, H. A.; Boquet, R. Some features of the parameter $\mathrm{k}$ of the GAB equation as applied to sorption isotherms of selected food materials. Journal of Food Engineering, v.15, p.75-82, 1992. http://dx.doi.org/10.1016/02608774(92)90041-4

Dieb, J. T.; Gurgel, C. M.; Dantas, T. P.; Medeiros, M. D. F. de. Secagem da polpa de graviola pelo processo foam-mat e avaliação sensorial do produto obtido. Tecnologia \& Informação, v.2, p.24-31, 2015.

Goula, A. M.; Karapantsios, T. D.; Achilias, D. S.; Adamopoulos, K. G. Water sorption isotherms and glass transition temperature of spray dried tomato pulp. Journal of Food Engineering, v.85, p.73-83, 2008. http://dx.doi.org/10.1016/j.jfoodeng.2007.07.015

Greespan, L. Humidity fixed points of binary saturated aqueous solutions. Journal of Research of the National of Standards A. Physics and Chemistry, v.81, p.89-96, 1977.

Hébrard, A.; Oulahna, D.; Galet, L.; Cuq, B.; Abecassis, J.; Fages, J. Hydration properties of durum wheat semolina: Influence of particle size. Powder Technology, v.130, p.211-218, 2003. http:// dx.doi.org/10.1016/S0032-5910(02)00268-1

IAL - Instituto Adolfo Lutz. Normas analíticas do Instituto Adolfo Lutz: Métodos químicos e físicos para análise de alimentos. 4.ed. São Paulo: IAL, 2008. 1020p.

Kurozawa, L. E.; El-Aouar, A. A.; Murr, F. E. Obtenção de isotermas de dessorção de cogumelo in natura e desidratado osmoticamente. Ciência e Tecnologia de Alimentos, v.25, p.828834, 2005. http://dx.doi.org/10.1590/S0101-20612005000400033

Lavoyer, F. C. G.; Gabas, A. L.; Oliveira, W. P.; Telis-Romero, J. Study of adsorption isotherms of green coconut pulp. Food Science and Technology, v.33, p.68-74, 2013. http://dx.doi.org/10.1590/ S0101-20612013005000017

Lima, J. P. de.; Rodrigues, L. F.; Monteiro, A. G. D. P.; Boas, E. V. de B. V. Climacteric pattern of mangaba fruit (Hancornia speciosa Gomes) and its responses to temperature. Scientia Horticulturae, v.197, p.399-403, 2015. http://dx.doi.org/10.1016/j.scienta.2015.09.059

Lomauro, C. J.; Bakshi, A. S.; Labuza, T. P. Evaluation of food moisture sorption isotherm equations. Part I: Fruit, vegetable and meat products. Lebensmittel- Wissenschaft \& Technologie, v.18, p.111117, 1985. http://dx.doi.org/10.1111/j.1365-2621.1985.tb13411.x

Mil, E.; Rodrigues, S.; Afonso, M. R. A.; Costa, J. M. C. da. Mathematical modeling for isotherms of mango pulp powder, obtained by atomization. Journal of Encapsulation and Adsorption Sciences, v.4, p.8-14, 2014. http://dx.doi.org/10.4236/jeas.2014.41002

Moreira, T. B.; Rocha, E. M. F. F.; Afonso, M. R.; Costa, J. M. C. da. Comportamento das isotermas de adsorção do pó da polpa de manga liofilizada. Revista Brasileira de Engenharia Agrícola e Ambiental, v.17, p.1093-1098, 2013. http://dx.doi.org/10.1590/ S1415-43662013001000011

Muzaffar, K.; Kumar, P. Moisture sorption isotherms and storage study of spray dried tamarind pulp powder. Powder Technology, v.291, p.322-327, 2016. http://dx.doi.org/10.1016/j.powtec.2015.12.046

Oikonomopoulou, V. P.; Krokida, M. K; Karathanos, V. K. The influence of freeze drying conditions on microstructural changes of food products. Procedia Food Science, v.1, p.647-654, 2011. http://dx.doi.org/10.1016/j.profoo.2011.09.097
Oliveira, D. M.; Clemente, E.; Costa, J. M. C. da. Hygroscopic behavior and degree of caking of grugru palm (Acrocomia aculeata) powder. Journal of Food Science and Technology, v.51, p.2783-2789, 2014a. https://doi.org/10.1007/s13197-012-0814-9

Oliveira, G. S.; Costa, J. M. C. da; Afonso, M. R. A. Caracterização e comportamento higroscópico do pó da polpa de cajá liofilizada. Revista Brasileira de Engenharia Agrícola e Ambiental, v.18, p.1059-1064, 2014b. http://dx.doi.org/10.1590/1807-1929/ agriambi.v18n10p1059-1064

Oliveira, V. S. de; Afonso, M. R. A.; Costa, J. M. C. da. Physico chemical and hygroscopic behavior of sapodilla lyophilized. Revista Ciência Agronômica, v.42, p.342-348, 2011. http://dx.doi.org/10.1590/ S1806-66902011000200012

Ribeiro, L. C.; Costa, J. M. C. da; Afonso, M. R. A. Hygroscopic behavior of lyophilized acerola pulp powder. Revista Brasileira de Engenharia Agrícola e Ambiental, v.20, p.269-274, 2016. http:// dx.doi.org/10.1590/1807-1929/agriambi.v20n3p269-274

Santana, R. F. de; Oliveira Neto, E. R. de; Santos, A. V.; Soares, C. M. F.; Lima, Á. S.; Cardoso, J. C. Water sorption isotherm and glass transition temperature of freeze-dried Syzygium cumini fruit (jambolan). Journal of Thermal Analysis and Calorimetry, v.120, p.519-524, 2015. https://doi.org/10.1007/s10973-014-4014-x

Santos, A. A. C. dos; Florêncio, A. K. G. D.; Rocha, É. M. de. F. F.; Costa, J. M. C. da. Avaliação físico-química e comportamento higroscópico de goiaba em pó obtida por spray-dryer. Revista Ciência Agronômica, v.20, p.508-514, 2014. http://dx.doi. org/10.1590/S1806-66902014000300010

Santos, J. T. S.; Costa, F. S. C.; Soares, D. S. C.; Campos, A. F. P.; Carnelossi, M. A. G.; Nunes, T. P.; Oliveira Júnior, A. M. Avaliação de mangaba liofilizada através de parâmetros físicoquímicos. Scientia Plena, v.8, p.1-5, 2012.

Silva, M. P. da; Gomes, F. dos S.; Freire Júnior, M.; Cabral, L. M. C. Avaliação dos efeitos da radiação gama na conservação da qualidade da polpa da amora-preta (Rubus spp L.). Revista Brasileira de Fruticultura, v.36, p.620-627, 2014. http://dx.doi. org/10.1590/0100-2945-218/13

Soares, D. C.; Santos, J. T. S.; Costa, D. G.; Abud, A. K. S.; Nunes, T. P.; Figueiredo, A. V. D.; Oliveira Júnior, A. M. de. Evaluation of Hancornia speciosa Gomes lyophilization at different stages of maturation. International Journal of Biological, Veterinary, Agricultural and Food Engineering, v.8, p.118-122, 2014.

Soares, F. P.; Paiva, R.; Alvarenga, A. A. de; Nery, F. C.; Vargas, D. P.; Silva, D. R. G. Taxa de multiplicação e efeito residual de diferentes fontes de citocinina no cultivo in vitro de Hancornia speciosa Gomes. Ciência e Agrotecnologia, v.35, p.152-157, 2011. http:// dx.doi.org/10.1590/S1413-70542011000100019

Sousa, K. dos S. M. de; Figueirêdo, R. M. F. de; Queiroz, A. J. de M.; Fernandes, T. K. da S. Production and characterization of atemoya pulp powder. Revista Brasileira de Fruticultura, v.37, p.718-728, 2015. http://dx.doi.org/10.1590/0100-2945-135/14

Strohecker, R.; Henning, H. M. Análises de vitaminas: Métodos comprobados. 1.ed. Madrid: Paz Montalvo, 1967. 428p. 